Jpn. J. Oral Biol., 26 : 1012-1022, 1984.

\title{
早期繩文時代長野県杤原岩蔭遺跡出土の哺乳動物
}

\author{
第 5 報 ノウサギの歯と頭蓋骨の大きさ
}

宮 尾 獄 雄* 子 安 和 弘 ${ }^{*}$ 西 沢 寿 晃 ${ }^{* *}$
愛知学院大学歯学部第二解剖学教室*
信州大学医学部第二解剖学教室
[受付 : 昭和 59 年 7 月 13 日]

\section{Mammalian remains of the earliest Jomon period at the rockshelter site of Tochibara, Nagano., Japan}

V. Size comparison of teeth and skull between prehistoric and recent population of the Japanese hare, Lepus brachyurus (Leporidae, Lagomorpha)

Takeo Miyao ${ }^{1 /}$, Kazuhiro Koyasu ${ }^{1 /}$ and Toshiaki Nishizawa ${ }^{2>}$

1) Department of Anatomy, School of Dentistry, Aichi-Gakuin University, 2-11, Suemoridori, Chikusa-ku, Nagoya City 464

2) Department of Anatomy, School of Medicine, Sinshu University, 3-1-1, Asahi, Matsumoto City 390

[Accepted for publication: July 13, 1984]

Key words : teeth morphology / evolution/ quaternary fossil / hare

Abstract: The Japanese hare, Lepus brachyurus, was one of the most abundant species among the mammalian bone remains excavated from the lower part of the rockshelter site at Tochibara, Nag. ano Prefecture, Japan. The greater part of this archaeological site belongs to the earliest Jomon period and the age of its lower part was indicated as $8,500-9,000$ years B. P. by carbon-14 determination.

The size and proportion of the teeth and skull were compared between prehistoric and recent populations of the hare. Recent materials were collected from the eastern part of Nagano Pref. adjacent to Tochibara site.

Mesiodistal (MD) and buccolingual (BL) crown diameters of the cheek teeth were generally larger in the prehistoric hare. The chronological size differences of these parameters had a tendency to become larger in the middle part of cheek teeth rows and smaller in incisors and both ends of the cheek teeth rows.

Lower temperature of the earliest Jomon period was suggested to be one of the most important factors that caused the size differences between the two chronological hare populations.

\section{緒言}

1965年から1978年にわたって行なわれた 調查に

\footnotetext{
*名古屋市千種区未盛通 2-11（广 464）

**松本市旭 3-1-1 (产 390)
}

よって，杤原岩蔭遺跡（長野県南佐久郡北相木村 杤原）からは早期繩文時代に属する人骨，文化遺 物，ならびに繩文人の食物残渣と思われる各種 の動物骨が 発堀されている ${ }^{1,2)}$ 。著者らは出土し た哺乳動物の 遺存骨に 関して解析を 続けている 
が3-7)，前報においては当時のノウサギ（Lepus brachyurus）の四肢骨が現生のそれより全般的に 大型であったという結果を報告した ${ }^{6)}$ 。

本報では前報にひきつづき，出土したノウサギ の歯と頭蓋骨の大きさを現生のそれと比較検討し た結果を報告する。

\section{材料および方法}

杤原岩院遺跡から出土したノウサギの 歯の個数 と計測に用いた個数を Table 1 に示す。ノウサギ

Table 1 Number of excavated and measured teeth of Lepus brachyurus from the rockshelter site of Tochibara, Nagano Prefecture (prehistoric population). Right and left teeth apparently belong. ing to the same animal were counted as one specimen

\begin{tabular}{|c|c|c|c|}
\hline Character & $\begin{array}{l}\text { Number of } \\
\text { excavated } \\
\text { teeth }\end{array}$ & $\begin{array}{c}\text { Frequency } \\
(\%)\end{array}$ & $\begin{array}{l}\text { Number of } \\
\text { measured } \\
\text { teeth }\end{array}$ \\
\hline
\end{tabular}

\begin{tabular}{|c|c|c|c|}
\hline \multicolumn{4}{|c|}{ upper teeth row } \\
\hline I1 & 17 & 7.59 & 16 \\
\hline $\mathrm{I} 2$ & 0 & 0.00 & - \\
\hline $\mathrm{P} 2$ & 7 & 3.13 & 6 \\
\hline P3 & 12 & 5.36 & 12 \\
\hline P4 & 9 & 4.02 & 9 \\
\hline M1 & 8 & 3.57 & 8 \\
\hline M2 & 6 & 2.68 & 6 \\
\hline M3 & 3 & 1.34 & 3 \\
\hline \multicolumn{4}{|c|}{ lower teeth row } \\
\hline I1 & 27 & 12.05 & 26 \\
\hline $\mathrm{P} 3$ & 22 & 9.82 & 17 \\
\hline $\mathrm{P} 4$ & 28 & 12.50 & 26 \\
\hline M1 & 29 & 12.95 & 28 \\
\hline M2 & 22 & 9.82 & 22 \\
\hline M3 & 11 & 4.91 & 8 \\
\hline unknown & 23 & 10.27 & - \\
\hline Total & 224 & 100.0 & 187 \\
\hline
\end{tabular}

の菌式は $2 \cdot 0 \cdot 3 \cdot 3 / 1 \cdot 0 \cdot 2 \cdot 3=28$ で あり (Fig. 1)，永久歯で出土しなかったのは上顎 第 2 切歯 $\left(\mathrm{I}^{2}\right)$ のみであった。乳歯は全く発見さ れていない。出土しなかった $\mathrm{I}^{2}$ は退化傾向の著 しいきわめて小型の歯であり，さらに歯槽から脱 落しやすい単純な形態をしていることも発見され
にくい原因であろう。この傾向は他の遺跡でもみ られる ${ }^{8)}$ 。上・下顎第 3 大臼歯 $\left(\mathrm{M}^{3} / \mathrm{M}_{3}\right)$ も退化傾 向が著しいが，これらの歯は比較的に歯槽から脱 落しにくい形態をしているので，䪽骨に植立した 状態で出土する場合がみられた。䫈骨から脱落し た遊離歯の場合, 上頡煩歯列に属する $\mathrm{P}^{4} \cdot \mathrm{M}^{1} \cdot \mathrm{M}^{2}$ および下顎煩歯列に属する $\mathrm{P}_{4} \cdot \mathrm{M}_{1} \cdot \mathrm{M}_{2}$ はそれぞれ 識別が困難であるから，これらの遊離歯は計測の 対象としなかった（Table 1 では unknown とし てある)。

計測には $1 / 20 \mathrm{~mm}$ 副尺付ノギスを用い，抜歯し た状態の歯の中央部において近遠心径と煩舌径を 計測した (Fig. 1)。またこれらの計測值から副厚 指数と Rectangle を算出して各歯種の大きさと 形を比較するための指標とした。

舌骨以外の頭蓋骨の出土も比較的多かったが, これらの骨は破砕の程度が著しく，計測は煩骨弓 基部長 $(\mathrm{ZL})$ ，骨口蓋橋長 (PL)，および下顎歯 隙長（DL）の 3 部位についてのみ行なった（Fig. 1)。下䫟歯隙長の計測については大塚ほか ${ }^{91}$ を参 考にした。

日本産ノウサギの歯の大きさや体の大きさの地 理的変異については，まだ充分な検討がなされて いない。しかし, 今泉 ${ }^{10)}$ は本州産現生ノウサギを 体の大きさ, 特に足の長さの相違に基づいて 2 严 種に分類し, 山田 $\cdot$ 白石 ${ }^{11)}$ も山形産個体群と福岡 産個体群の比較を行なって上・下䪽の 煩歯列長, 鼻骨長, 大孔長, および煩骨弓幅に有意差を認めて いる。また, 宮尾・水野 ${ }^{12)}$ によると，，ウサギの 体の大きさには長野県内においてさえ地理的変異 が存在する。したがって早期繩文時代産,ウサギ との比較対照とした現生標本は，遺跡の位置して いる長野県東部地方（南佐久郡，北佐久郡，上田 市, 小県郡, 諏訪地方) の低山帯で採集された成体 40 頭（雄15頭, 雌 21 頭, 性別不明 4 頭）を用いた。

\section{結 果}

早期繩文時代および現生ノウサギの 歯冠近遠心 径, 煩舌径, Rectangle および愊厚指数の統計量 を Tables 2-9 に示した。また，頭蓋骨の大きさ に関する統計量を Table 10 に示した。

1）歯冠近遠心径 : 現生ノウサギの歯の近遠心 


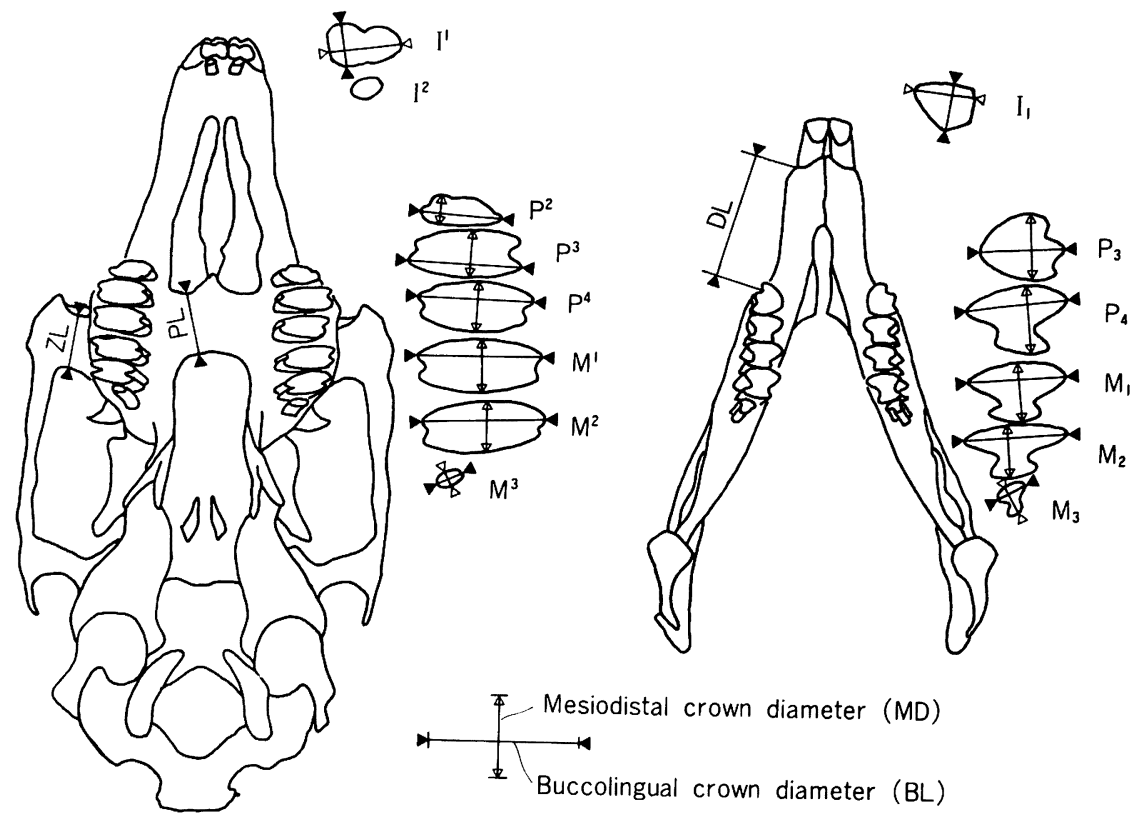

Fig. 1 Skull of the Japanese hare (Lepus brachyurus), showing the measurements adopted in this study. Left : ventral view of cranium. Right: dorsal view of mandible. DL : diastema length. PL: palatal length. ZL: zygomatic length.

Table 2 Descriptive statistics for MDs (mesiodistal crown diameters) (mm) of the dentition of Lepus brachyurus from the eastern part of Nagano Prefecture (recent population)

\begin{tabular}{|c|c|c|c|c|c|c|c|c|c|}
\hline \multirow{2}{*}{ Character } & \multicolumn{4}{|c|}{ Recent males } & \multicolumn{4}{|c|}{ Recent females } & \multirow{2}{*}{$\begin{array}{l}\text { Significance } \\
(\mathrm{t}-\text { Test) }\end{array}$} \\
\hline & $\mathrm{N}$ & $\overline{\mathrm{X}}$ & $\mathrm{SD}$ & $\mathrm{CV}$ & $\mathrm{N}$ & $\overline{\mathrm{X}}$ & $\mathrm{SD}$ & $\mathrm{CV}$ & \\
\hline \multicolumn{10}{|c|}{ upper teeth row } \\
\hline I1 & 15 & 3.11 & 0.16 & 5.20 & 20 & 3.19 & 0.19 & 5.89 & - \\
\hline $\mathrm{P} 2$ & 15 & 2.23 & 0.13 & 5.90 & 20 & 2.21 & 0.14 & 6.26 & - \\
\hline $\mathrm{P} 3$ & 15 & 2.75 & 0.15 & 5.30 & 21 & 2.76 & 0.14 & 5.20 & - \\
\hline $\mathrm{P} 4$ & 15 & 2.74 & 0.14 & 5.14 & 21 & 2.80 & 0.14 & 5.08 & - \\
\hline M1 & 15 & 2.58 & 0.14 & 5.52 & 21 & 2.61 & 0.15 & 5.64 & - \\
\hline $\mathrm{M} 2$ & 15 & 2.36 & 0.11 & 4.69 & 21 & 2.37 & 0.11 & 4.58 & - \\
\hline M3 & 15 & 1.02 & 0.07 & 7.11 & 20 & 0.99 & 0.10 & 9.71 & - \\
\hline \multicolumn{10}{|c|}{ lower teeth row } \\
\hline I1 & 15 & 3.24 & 0.19 & 5.72 & 21 & 3.27 & 0.16 & 4.95 & - \\
\hline P3 & 15 & 4.27 & 0.25 & 5.82 & 21 & 4.22 & 0.21 & 4.95 & - \\
\hline $\mathrm{P} 4$ & 15 & 3.36 & 0.18 & 5.42 & 21 & 3.39 & 0.11 & 3.29 & - \\
\hline M1 & 15 & 3.31 & 0.19 & 5.83 & 21 & 3.33 & 0.12 & 3.49 & - \\
\hline M2 & 15 & 3.35 & 0.19 & 5.63 & 21 & 3.36 & 0.08 & 2.37 & - \\
\hline M3 & 15 & 2.21 & 0.13 & 5.97 & 20 & 2.25 & 0.10 & 4.60 & - \\
\hline
\end{tabular}

${ }^{*} \mathrm{p}<0.05$ 
Table 3 Descriptive statistics for MDs ( $\mathrm{mm}$ ) of the dentition of prehistoric and recent populations of Lepus brachyurus

\begin{tabular}{|c|c|c|c|c|c|c|c|c|c|c|}
\hline \multirow{2}{*}{ Character } & \multicolumn{4}{|c|}{ Prehistoric material } & \multicolumn{4}{|c|}{ Recent material } & \multirow{2}{*}{$\begin{array}{l}\text { Significance } \\
\quad(t-T e s t)\end{array}$} & \multirow{2}{*}{$\begin{array}{l}\text { Ratios of } \\
\text { difference }\end{array}$} \\
\hline & $\mathrm{N}$ & $\overline{\mathrm{X}}$ & $\mathrm{SD}$ & $\mathrm{CV}$ & $\mathrm{N}$ & $\overline{\mathrm{X}}$ & $\mathrm{SD}$ & $\mathrm{CV}$ & & \\
\hline \multicolumn{11}{|c|}{ upper teeth row } \\
\hline I1 & 16 & 3.12 & 0.18 & 5.70 & 39 & 3.15 & 0.17 & 5.47 & - & -0.95 \\
\hline $\mathrm{P} 2$ & 6 & 2.34 & 0.16 & 6.95 & 39 & 2.22 & 0.21 & 5.20 & - & 5.41 \\
\hline P3 & 12 & 2.95 & 0.16 & 5.33 & 40 & 2.76 & 0.16 & 5.66 & $* *$ & 6.88 \\
\hline $\mathrm{P} 4$ & 9 & 2.93 & 0.09 & 3.24 & 40 & 2.77 & 0.16 & 5.88 & $* *$ & 5.78 \\
\hline M1 & 8 & 2.68 & 0.12 & 4.41 & 40 & 2.59 & 0.15 & 5.81 & - & 3.47 \\
\hline M2 & 6 & 2.49 & 0.03 & 1.31 & 40 & 2.37 & 0.12 & 5.19 & $* *$ & 4.43 \\
\hline M3 & 3 & 1.03 & 0.06 & 5.59 & 39 & 1.00 & 0.09 & 8.72 & - & 3.00 \\
\hline \multicolumn{11}{|c|}{ lower teeth row } \\
\hline I1 & 26 & 3.23 & 0.13 & 4.10 & 39 & 3.25 & 0.17 & 5.18 & - & -0.62 \\
\hline P3 & 17 & 4.43 & 0.25 & 5.60 & 39 & 4.23 & 0.24 & 5.65 & $* *$ & 4.73 \\
\hline $\mathrm{P} 4$ & 26 & 3.48 & 0.13 & 3.75 & 39 & 3.37 & 0.16 & 4.66 & $* *$ & 3.26 \\
\hline M1 & 28 & 3.44 & 0.14 & 4.08 & 39 & 3.32 & 0.16 & 4.75 & $* *$ & 3.61 \\
\hline M2 & 22 & 3.48 & 0.14 & 3.99 & 39 & 3.36 & 0.14 & 4.05 & $* *$ & 3.57 \\
\hline M3 & 8 & 2.39 & 0.14 & 5.78 & 39 & 2.23 & 0.11 & 5.09 & $* *$ & 7.17 \\
\hline
\end{tabular}

$* \mathrm{p}<0.05 \quad * * \mathrm{p}<0.01$

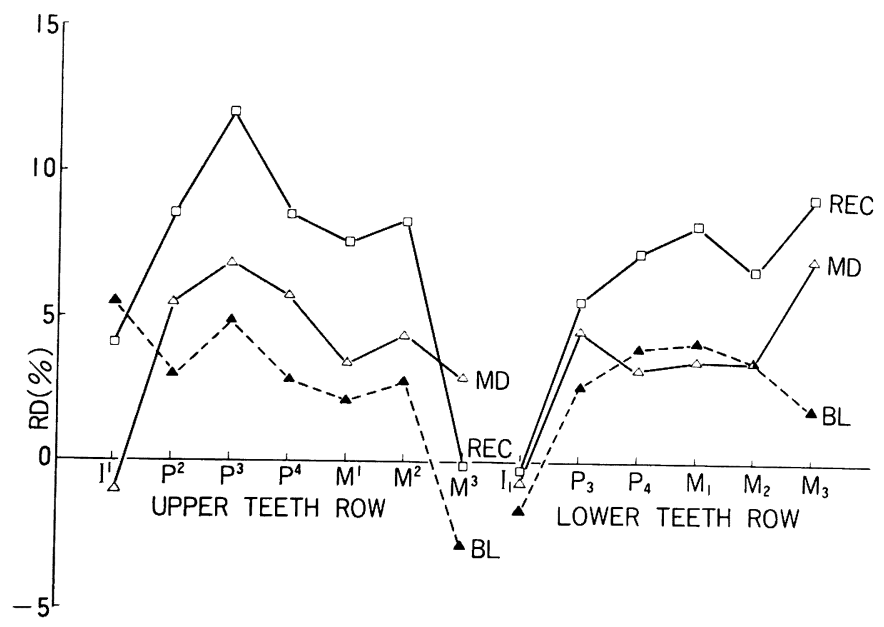

Fig. 2 Ratios of difference (RD) for the teeth sizes (MD, BL, and REC) between prehistoric and recent populations of Lepus brachyurus. For teeth mesurements, see Fig. 1.

径は，計測したすべての歯種で性差が認められな かった (Table 2)。そこで現生ノウサギの雌雄お よび性別不明を一括して取り扱い，早期繩文時代 産ノウサギの歯と比較した（Table 3)。

近遠心径の平均值は, 切歯 $\left(\mathrm{I}^{1} / \mathrm{I}_{1}\right)$ において現 生が大であるほかはすべての煩歯 $\left(\mathrm{P}^{2} \sim \mathrm{M}^{3} / \mathrm{P}_{3} \sim\right.$
$\mathrm{M}_{3}$ ）で早期繩文時代産が大である。平均值の差の 検定を $\mathrm{t}$ 検定を用いて行なうと, 上領では $\mathrm{P}^{3} \cdot \mathrm{P}^{4}$. $\mathrm{M}^{2}$ において，下顎では $\mathrm{P}_{3} \cdot \mathrm{P}_{4} \cdot \mathrm{M}_{1} \cdot \mathrm{M}_{2} \cdot \mathrm{M}_{3}$ におい て有意差が認められた $(\mathrm{p}<0.01)$ 。現生に対する 早期繩文時代産ノウサギの歯冠近遠心径の 大型化

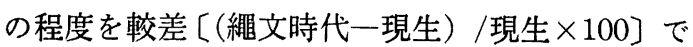


Table 4 Descriptive statistics for BLs (buccolingual crown diameters) (mm) of the dentition of recent population of Lepus brachyurus

\begin{tabular}{|c|c|c|c|c|c|c|c|c|c|}
\hline \multirow{2}{*}{ Character } & \multicolumn{4}{|c|}{ Recent males } & \multicolumn{4}{|c|}{ Recent females } & \multirow{2}{*}{$\begin{array}{c}\text { Significance } \\
(\mathrm{t}-\mathrm{Test})\end{array}$} \\
\hline & $\mathrm{N}$ & $\overline{\mathrm{X}}$ & $\mathrm{SD}$ & $\mathrm{CV}$ & $\mathrm{N}$ & $\overline{\mathrm{X}}$ & $\mathrm{SD}$ & $\mathrm{CV}$ & \\
\hline \multicolumn{10}{|c|}{ upper teeth row } \\
\hline I1 & 15 & 2.36 & 0.23 & 9.85 & 20 & 2.39 & 0.19 & 8.15 & - \\
\hline $\mathrm{P} 2$ & 15 & 4.02 & 0.18 & 4.38 & 20 & 3.96 & 0.24 & 6.16 & - \\
\hline P3 & 15 & 5.28 & 0.17 & 3.22 & 21 & 5.35 & 0.24 & 4.43 & - \\
\hline $\mathrm{P} 4$ & 15 & 5.09 & 0.17 & 3.36 & 21 & 5.17 & 0.24 & 4.60 & - \\
\hline M1 & 15 & 4.73 & 0.21 & 4.49 & 21 & 4.83 & 0.24 & 4.97 & - \\
\hline $\mathrm{M} 2$ & 15 & 4.49 & 0.18 & 3.92 & 21 & 4.53 & 0.20 & 4.37 & - \\
\hline M3 & 15 & 1.81 & 0.17 & 9.30 & 20 & 1.84 & 0.13 & 7.31 & - \\
\hline \multicolumn{10}{|c|}{ lower teeth row } \\
\hline I1 & 15 & 2.66 & 0.16 & 6.19 & 21 & 2.65 & 0.17 & 6.53 & - \\
\hline P3 & 15 & 3.66 & 0.26 & 7.19 & 21 & 3.70 & 0.22 & 5.87 & - \\
\hline $\mathrm{P} 4$ & 15 & 3.92 & 0.27 & 6.84 & 21 & 3.97 & 0.15 & 3.83 & - \\
\hline M1 & 15 & 3.72 & 0.23 & 6.19 & 21 & 3.77 & 0.14 & 3.77 & - \\
\hline M2 & 15 & 3.65 & 0.24 & 6.45 & 21 & 3.66 & 0.15 & 4.08 & - \\
\hline M3 & 15 & 2.01 & 0.14 & 6.83 & 20 & 2.05 & 0.09 & 4.38 & - \\
\hline
\end{tabular}

$* \mathrm{p}<0.05$

Table 5 Descriptive statistics for BLs $(\mathrm{mm})$ of the dentition of prehistoric and recent populations of Lepus brachyurus

\begin{tabular}{|c|c|c|c|c|c|c|c|c|c|c|}
\hline \multirow{2}{*}{ Character } & \multicolumn{4}{|c|}{ Prehistoric material } & \multicolumn{4}{|c|}{ Recent material } & \multirow{2}{*}{$\begin{array}{l}\text { Significance } \\
(\mathrm{t}-\text { Test })\end{array}$} & \multirow{2}{*}{$\begin{array}{l}\text { Ratios of } \\
\text { difference }\end{array}$} \\
\hline & $\mathrm{N}$ & $\overline{\mathrm{X}}$ & $\mathrm{SD}$ & $\mathrm{CV}$ & $\mathrm{N}$ & $\overline{\mathrm{X}}$ & $\mathrm{SD}$ & $\mathrm{CV}$ & & \\
\hline \multicolumn{11}{|c|}{ upper teeth row } \\
\hline I1 & 16 & 2.48 & 0.15 & 5.91 & 39 & 2.36 & 0.21 & 8.81 & $*$ & 5.51 \\
\hline $\mathrm{P} 2$ & 6 & 4.11 & 0.09 & 2.09 & 39 & 3.99 & 0.21 & 5.20 & $*$ & 3.01 \\
\hline P3 & 12 & 5.58 & 0.24 & 4.30 & 40 & 5.32 & 0.22 & 4.05 & $* *$ & 4.89 \\
\hline $\mathrm{P} 4$ & 9 & 5.28 & 0.15 & 2.81 & 40 & 5.13 & 0.23 & 4.51 & $*$ & 2.92 \\
\hline M1 & 8 & 4.97 & 0.23 & 4.71 & 40 & 4.77 & 0.25 & 5.14 & $*$ & 4.19 \\
\hline M2 & 6 & 4.64 & 0.19 & 4.05 & 40 & 4.51 & 0.20 & 4.37 & - & 2.88 \\
\hline M3 & 3 & 1.77 & 0.06 & 5.59 & 39 & 1.82 & 0.15 & 8.00 & - & -2.75 \\
\hline \multicolumn{11}{|c|}{ lower teeth row } \\
\hline I1 & 26 & 2.61 & 0.16 & 6.12 & 39 & 2.65 & 0.16 & 6.17 & - & -1.51 \\
\hline P3 & 17 & 3.76 & 0.22 & 5.79 & 39 & 3.66 & 0.25 & 6.85 & - & 2.73 \\
\hline $\mathrm{P} 4$ & 26 & 4.11 & 0.20 & 4.79 & 39 & 3.95 & 0.22 & 5.53 & $* *$ & 4.05 \\
\hline M1 & 28 & 3.91 & 0.19 & 4.92 & 39 & 3.75 & 0.18 & 4.92 & $* *$ & 4.27 \\
\hline $\mathrm{M} 2$ & 22 & 3.48 & 0.18 & 4.68 & 39 & 3.36 & 0.20 & 5.51 & $*$ & 3.57 \\
\hline M3 & 8 & 2.07 & 0.08 & 3.91 & 39 & 2.03 & 0.11 & 5.46 & - & 1.97 \\
\hline
\end{tabular}

表わすと，有意差のある歯種での較差の範囲は上 顎で4.43( $\left(\mathrm{M}^{2}\right) \sim 6.88\left(\mathrm{P}^{3}\right) \%$, 下顎では3.26 $\left(\mathrm{P}_{4}\right)$ 〜.17 $\left(\mathrm{M}_{3}\right) \%$ \%る（Fig. $\left.2 \mathrm{MD}\right)$ 。切歯では
上・下頡とも近遠心径の平均值が現生で大である が，その較差はごくわずかで有意差もない。

2）歯冠煩舌径：煩舌径においても，計測した 
Table 6 Descriptive statistics for RECs (rectangles) $\left(\mathrm{mm}^{2}\right)$ of the dentition of recent population of Lepus brachyurus

\begin{tabular}{|c|c|c|c|c|c|c|c|c|c|}
\hline \multirow{2}{*}{ Character } & \multicolumn{4}{|c|}{ Recent males } & \multicolumn{4}{|c|}{ Recent females } & \multirow{2}{*}{$\begin{array}{l}\text { Significance } \\
(\mathrm{t}-\text { Test })\end{array}$} \\
\hline & $\mathrm{N}$ & $\overline{\mathrm{X}}$ & $\mathrm{SD}$ & $\mathrm{CV}$ & $\mathrm{N}$ & $\overline{\mathrm{x}}$ & $\mathrm{SD}$ & $\mathrm{CV}$ & \\
\hline \multicolumn{10}{|c|}{ upper teeth row } \\
\hline I1 & 15 & 7.36 & 0.89 & 12.14 & 20 & 7.63 & 0.93 & 12.23 & - \\
\hline P2 & 15 & 9.00 & 0.80 & 8.95 & 20 & 8.80 & 0.93 & 10.59 & - \\
\hline P3 & 15 & 14.54 & 1.16 & 7.99 & 21 & 14.80 & 1.34 & 9.05 & - \\
\hline P4 & 15 & 13.95 & 1.07 & 7.64 & 21 & 14.49 & 1.30 & 8.99 & - \\
\hline M1 & 15 & 12.20 & 1.02 & 8.35 & 21 & 12.60 & 1.20 & 9.55 & - \\
\hline M2 & 15 & 10.61 & 0.82 & 7.74 & 21 & 10.76 & 0.86 & 8.00 & - \\
\hline M3 & 15 & 1.86 & 0.28 & 15.00 & 20 & 1.84 & 0.27 & 14.91 & - \\
\hline \multicolumn{10}{|c|}{ lower teeth row } \\
\hline I1 & 15 & 8.62 & 0.93 & 10.81 & 21 & 8.67 & 0.92 & 10.66 & - \\
\hline P3 & 15 & 15.67 & 1.96 & 12.50 & 21 & 15.61 & 1.42 & 9.09 & - \\
\hline $\mathrm{P} 4$ & 15 & 13.22 & 1.57 & 11.84 & 21 & 13.45 & 0.76 & 5.62 & - \\
\hline M1 & 15 & 12.34 & 1.47 & 11.93 & 21 & 12.55 & 0.74 & 5.89 & - \\
\hline M2 & 15 & 12.26 & 1.47 & 11.97 & 21 & 12.29 & 0.69 & 5.62 & - \\
\hline M3 & 15 & 4.44 & 0.49 & 11.11 & 20 & 4.62 & 0.32 & 6.92 & - \\
\hline
\end{tabular}

${ }^{*} \mathrm{p}<0.05$

すべての歯種で現生ノウサギに性差が認められな かった（Table 4)。現生ノウサギを一括して早期 繩文時代産と比較した結果, 上顎歯列では $\mathrm{I}^{1} \cdot \mathrm{P}^{2}$. $\mathrm{P}^{3} \cdot \mathrm{P}^{4} \cdot \mathrm{M}^{1}$ で, 下顎歯列では $\mathrm{P}_{4} \cdot \mathrm{M}_{1} \cdot \mathrm{M}_{2}$ の煩舌径 において早期繩文時代産が現生より有意に大であ った (Table 5)。有意差のある歯種での較差の範 囲は上顎で $2.92\left(\mathrm{P}^{4}\right) \sim 5.51\left(\mathrm{I}^{1}\right) \%$ ，下顎では3.57 $\left(\mathrm{M}^{2}\right) \sim 4.27\left(\mathrm{M}_{1}\right) \%$ \%あ (Fig. $\left.2 \mathrm{BL}\right) 。 \mathrm{I}_{1}$ と $\mathrm{M}^{3}$ の煩舌径平均值は繩文時代産より 現生が大き いが有意差はなく，その較差も比較的小さい。た だし， $\mathrm{M}^{3}$ については早期繩文時代産の計測個体 数が少ない $(\mathrm{N}=3)$ ので注意を要する。

3） Recangle：Rectangle は近遠心径 $\times$ 煩舌径 で与えられる歯冠の面積指数である。現生ノウサ ギでは計測したすべての歯種で性差が認められな かった（Table 6)。現生と早期繩文時代産ノウサ ギとの比較では, $\mathrm{I}_{1}$ と $\mathrm{M}^{3}$ 以外の上・下頡煩歯で 早期繩文時代産ノウサギが全般的に大型であった (Table 7)。有意差の認められた 歯種における Rectangle の較差の範囲は上頡で $8.33\left(\mathrm{M}^{2}\right)$ $12.04\left(\mathrm{P}^{3}\right) \%$ ，下顎では6.65 $\left(\mathrm{M}_{2}\right) \sim 9.25\left(\mathrm{M}_{3}\right) \%$ である(Fig. 2 REC)。
4) 歯冠幅厚指数：幅厚指数は煩舌径/近遠心 径 $\times 100 （ \%)$ で与えられ, 歯冠の形(プロポーシ ヨン）を表わす指数である。現生ノウサギにおい てはこの指数に性差がなく（Table 8), 雌雄を一 括して早期繩文時代産と比較した（Table 9)。時 代を異にする 2 個体群間で幅厚指数に差の認めら れたのは, 上顎では $\mathrm{I}^{1}$ と $\mathrm{P}^{4}$ であり, 下頡では $\mathrm{M}_{3}$ のみであった $(\mathrm{p}<0.05)$ 。即ち, これらの歯 種では歯冠の形に時代的な差異が認められるが, 他の歯種では差異が認められない。

幅厚指数の較差を求めると, 正の值をとるもの が 4 歯種, 負の值をとるものが 9 歯種あった ( Table 9)。正の值をとる歯種では早期繩文時代産の 歯が煩舌方向に相対的に大きく，負の值をとる場 合は早期繩文時代産が近遠心方向に相対的に大き かったことを示している。

5）歯の大きさの変異性と時代較差：現生ノウ サギの歯の大きさの変異性は歯種によって異な り，また同一歯種でも近遠心径と煩舌径では異な る (Fig. 3)。歯の大きさの指標である Rectangle をみると上狉歯列では $\mathrm{M}^{3}$ の変異性が最も高く, $\mathrm{I}^{1}$ がこれについでおり, 下䫓歯列では $\mathrm{P}_{3}$ の変異 
Table 7 Descriptive statistics for RECs $\left(\mathrm{mm}^{2}\right)$ of the dentition of prehistoric and recent populations of Lepus brachyurus

\begin{tabular}{|c|c|c|c|c|c|c|c|c|c|c|}
\hline \multirow{2}{*}{ Character } & \multicolumn{4}{|c|}{ Prehistoric material } & \multicolumn{4}{|c|}{ Recent material } & \multirow{2}{*}{$\begin{array}{c}\text { Significance } \\
(\mathrm{t}-\mathrm{Test})\end{array}$} & \multirow{2}{*}{$\begin{array}{l}\text { Ratios of } \\
\text { difference }\end{array}$} \\
\hline & $\mathrm{N}$ & $\overline{\mathrm{X}}$ & $\mathrm{SD}$ & $\mathrm{CV}$ & $\mathrm{N}$ & $\overline{\mathrm{X}}$ & $\mathrm{SD}$ & $\mathrm{CV}$ & & \\
\hline \multicolumn{11}{|c|}{ upper teeth row } \\
\hline I1 & 16 & 7.76 & 0.69 & 8.85 & 39 & 7.46 & 0.90 & 12.03 & - & 4.02 \\
\hline $\mathrm{P} 2$ & 6 & 9.62 & 0.80 & 8.35 & 39 & 8.86 & 0.85 & 9.57 & $*$ & 8.58 \\
\hline P3 & 12 & 16.47 & 1.42 & 8.64 & 40 & 14.70 & 1.35 & 9.19 & $* *$ & 12.04 \\
\hline $\mathrm{P} 4$ & 9 & 15.47 & 0.74 & 4.80 & 40 & 14.25 & 1.40 & 9.84 & $* *$ & 8.56 \\
\hline M1 & 8 & 13.33 & 1.10 & 8.24 & 40 & 12.39 & 1.23 & 9.91 & - & 7.59 \\
\hline M2 & 6 & 11.57 & 0.55 & 4.78 & 40 & 10.68 & 0.94 & 8.83 & $*$ & 8.33 \\
\hline M3 & 3 & 1.83 & 0.14 & 7.77 & 39 & 1.84 & 0.27 & 14.84 & - & -0.54 \\
\hline \multicolumn{11}{|c|}{ lower teeth row } \\
\hline I1 & 26 & 8.44 & 0.76 & 8.98 & 39 & 8.63 & 0.90 & 10.43 & 一 & -2.20 \\
\hline P3 & 17 & 16.70 & 1.77 & 10.61 & 39 & 15.52 & 1.77 & 11.42 & $*$ & 7.60 \\
\hline $\mathrm{P} 4$ & 26 & 14.32 & 1.11 & 7.75 & 39 & 13.35 & 1.25 & 9.39 & $* *$ & 7.27 \\
\hline M1 & 28 & 13.48 & 1.13 & 8.36 & 39 & 12.45 & 1.13 & 9.06 & $* *$ & 8.27 \\
\hline $\mathrm{M} 2$ & 22 & 13.15 & 0.99 & 7.56 & 39 & 12.33 & 1.12 & 9.12 & $* *$ & 6.65 \\
\hline M3 & 8 & 4.96 & 0.44 & 8.77 & 39 & 4.54 & 0.40 & 8.87 & $*$ & 9.25 \\
\hline
\end{tabular}

$* \mathrm{p}<0.05 \quad * * \mathrm{p}<0.01$

Table 8 Descrptive statistics for $\mathrm{BL} / \mathrm{MD}$ indices (\%) of the dentition of recent population of Lepus brachyurus

\begin{tabular}{|c|c|c|c|c|c|c|c|c|c|}
\hline \multirow{2}{*}{ Character } & \multicolumn{4}{|c|}{ Recent males } & \multicolumn{4}{|c|}{ Recent females } & \multirow{2}{*}{$\begin{array}{l}\text { Significance } \\
\qquad(\mathrm{t}-\mathrm{Test})\end{array}$} \\
\hline & $N$ & $\overline{\mathrm{X}}$ & $\mathrm{SD}$ & $\mathrm{CV}$ & $\mathrm{N}$ & $\overline{\mathrm{X}}$ & $\mathrm{SD}$ & $\mathrm{CV}$ & \\
\hline \multicolumn{10}{|c|}{ upper teeth row } \\
\hline I1 & 15 & 76.04 & 7.72 & 10.15 & 20 & 75.02 & 5.34 & 7.12 & - \\
\hline $\mathrm{P} 2$ & 15 & 180.82 & 9.44 & 5.22 & 20 & 179.37 & 11.43 & 6.37 & - \\
\hline P3 & 15 & 192.52 & 6.82 & 3.54 & 21 & 194.13 & 6.17 & 3.18 & - \\
\hline $\mathrm{P} 4$ & 15 & 186.15 & 7.56 & 4.06 & 21 & 184.66 & 6.10 & 3.30 & - \\
\hline M1 & 15 & 183.68 & 9.45 & 5.14 & 21 & 185.40 & 8.79 & 4.74 & - \\
\hline M2 & 15 & 190.39 & 7.12 & 3.74 & 21 & 191.19 & 7.33 & 3.83 & - \\
\hline M3 & 15 & 176.73 & 12.74 & 7.21 & 20 & 186.58 & 16.31 & 8.74 & - \\
\hline \multicolumn{10}{|c|}{ lower teeth row } \\
\hline I1 & 15 & 82.15 & 3.97 & 4.84 & 21 & 81.03 & 3.61 & 4.45 & - \\
\hline P3 & 15 & 85.77 & 3.30 & 3.85 & 21 & 87.75 & 1.42 & 9.09 & - \\
\hline $\mathrm{P} 4$ & 15 & 116.64 & 4.55 & 3.90 & 21 & 117.23 & 4.92 & 4.19 & - \\
\hline M1 & 15 & 112.53 & 3.38 & 3.00 & 21 & 113.30 & 4.86 & 4.29 & - \\
\hline M2 & 15 & 109.17 & 3.57 & 3.27 & 21 & 109.04 & 3.95 & 3.62 & - \\
\hline M3 & 15 & 91.06 & 5.57 & 6.11 & 20 & 91.55 & 5.30 & 5.79 & - \\
\hline
\end{tabular}

$* \mathrm{p}<0.05$

性が最も高く， I 1 がこれについでいる。上・下顎 とも歯列中央部分の変異性は相対的に低い。大き さの変異性パターンは上狉と下顎で異なるが，近
遠心径と煩舌径のパターンはほぼ同一である (Fig. 3)。ただし，上顎では近遠心径が，下頡で は煩舌径がそれぞれ変異性が 全般的に高くなって 
Table 9 Descriptive statistics for BL/MD indices (\%) of the dentition of prehistoric and recent populations of Lepus brachyurus

\begin{tabular}{|c|c|c|c|c|c|c|c|c|c|c|}
\hline \multirow{2}{*}{ Character } & \multicolumn{4}{|c|}{ Prehistoric material } & \multicolumn{4}{|c|}{ Recent material } & \multirow{2}{*}{$\begin{array}{l}\text { Significance } \\
(\mathrm{t}-\mathrm{Test})\end{array}$} & \multirow{2}{*}{$\begin{array}{l}\text { Ratios of } \\
\text { difference }\end{array}$} \\
\hline & $\mathrm{N}$ & $\overline{\mathrm{X}}$ & $\mathrm{SD}$ & $\mathrm{CV}$ & $\mathrm{N}$ & $\overline{\mathrm{X}}$ & $\mathrm{SD}$ & $\mathrm{CV}$ & & \\
\hline \multicolumn{11}{|c|}{ upper teeth row } \\
\hline I1 & 16 & 79.71 & 6.29 & 7.89 & 39 & 74.85 & 6.34 & 8.47 & $*$ & 6.49 \\
\hline $\mathrm{P} 2$ & 6 & 176.32 & 9.96 & 5.65 & 39 & 179.93 & 10.45 & 5.81 & - & -2.01 \\
\hline $\mathrm{P} 3$ & 12 & 189.36 & 9.32 & 4.92 & 40 & 193.22 & 6.60 & 3.42 & - & -2.00 \\
\hline $\mathrm{P} 4$ & 9 & 180.28 & 6.85 & 3.80 & 40 & 185.66 & 6.90 & 3.72 & $*$ & -2.90 \\
\hline M1 & 8 & 185.63 & 7.01 & 3.78 & 40 & 184.62 & 8.55 & 4.63 & - & 0.55 \\
\hline $\mathrm{M} 2$ & 6 & 185.96 & 6.80 & 3.66 & 40 & 190.66 & 7.11 & 3.73 & - & -2.47 \\
\hline M3 & 3 & 171.21 & 8.25 & 4.82 & 39 & 182.37 & 14.79 & 8.11 & - & -6.12 \\
\hline \multicolumn{11}{|c|}{ lower teeth row } \\
\hline I1 & 26 & 81.05 & 4.27 & 5.27 & 39 & 81.68 & 3.66 & 4.48 & - & -0.77 \\
\hline P3 & 17 & 85.04 & 3.45 & 4.05 & 39 & 86.75 & 4.27 & 4.92 & - & -1.97 \\
\hline $\mathrm{P} 4$ & 26 & 118.11 & 4.32 & 3.66 & 39 & 117.31 & 4.67 & 3.98 & - & 0.68 \\
\hline M1 & 28 & 113.80 & 3.94 & 3.46 & 39 & 113.08 & 4.14 & 3.66 & - & 0.64 \\
\hline M2 & 22 & 108.47 & 4.86 & 4.48 & 39 & 109.19 & 3.94 & 3.61 & - & -0.66 \\
\hline M3 & 8 & 87.07 & 4.21 & 4.84 & 39 & 91.30 & 5.09 & 5.57 & $*$ & -4.63 \\
\hline
\end{tabular}

$* \mathrm{p}<0.05 \quad * * \mathrm{p}<0.01$

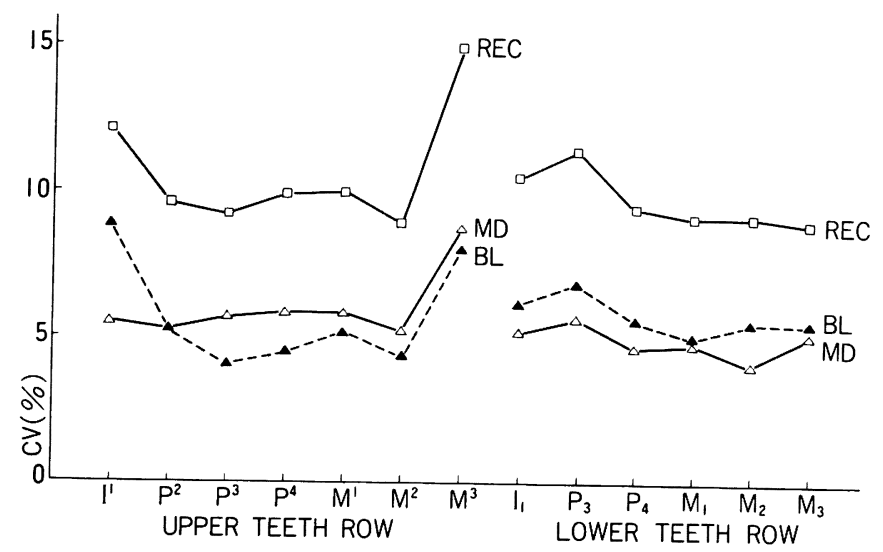

Fig. 3 Coefficients of variation (CV) for teeth sizes (MD, BL, and REC) in recent population of Lepus brachyurus. For teeth measurments, see Fig. 1.

いる。

各歯種における Rectangle の時代較差 (Fig. 2) と現生種の歯の Rectangle の変異倸数の相関をと ると, 上顎では -0.828 という極めて高い負の相 関関係が認められた。下顎では上顎ほど明僚では ないが， -0.389 という負の值が得られている。 即ち, 現生ノウサギで大きさの変異性が高い切歯 および煩歯列端に位置する歯種では 時代較差が少
なく，反対に変異性の低い煩歯列中央部に位置す る歯種で時代較差が大きい。

6）頭蓋骨の大きさ：頭蓋骨の計測部位（煩骨 弓基部長・骨口蓋橋長・下顎歯隙長）においても 歯と同様, 現生, ウサギに雌雄差は認められなか った（Table 10）。現生の雌雄を一括して早期繩 文時代産と比較すると， 3 計測部位のすべてにお いてその平均值が早期繩文時代産で大であったが 
Table 10 Descriptive statistics for measurements $(\mathrm{mm})$ of the skull of prehistoric and recent populations of Lepus brachyurus

\begin{tabular}{|c|c|c|c|c|c|c|c|c|c|c|c|c|}
\hline & \multicolumn{4}{|c|}{ ZL } & \multicolumn{4}{|c|}{ PL } & \multicolumn{4}{|c|}{$\mathrm{DL}$} \\
\hline & $\mathrm{N}$ & $\overline{\mathrm{X}}$ & $\mathrm{SD}$ & $\mathrm{CV}$ & $\mathrm{N}$ & $\overline{\mathrm{x}}$ & SD & $\mathrm{CV}$ & $\mathrm{N}$ & $\overline{\mathrm{X}}$ & SD & $\mathrm{CV}$ \\
\hline male & 15 & 5.58 & 0.39 & 7.01 & 15 & 7.84 & 0.67 & 8.58 & 15 & 16.92 & 1.14 & 6.75 \\
\hline female & 21 & 5.64 & 0.59 & 10.46 & 21 & 7.86 & 0.75 & 9.50 & 21 & 17.17 & 0.81 & 4.74 \\
\hline recent & 40 & 5.61 & 0.50 & 8.90 & 40 & 7.83 & 0.73 & 9.38 & 39 & 17.03 & 0.94 & 5.55 \\
\hline prehistoric & 16 & 5.87 & 0.50 & 8.49 & 7 & 8.34 & 0.63 & 7.52 & 19 & 17.51 & 0.84 & 4.80 \\
\hline
\end{tabular}

有意の差ではなかった $(\mathrm{P}>0.05)$ 。

\section{考察}

1965年から1978年にわたって 調査された杤原岩 蔭遺跡は, $5.5 \mathrm{~m}$ に及ぶ推積層を有し, 約 $231 \mathrm{~kg}$ に達する動物骨の出土がみられた。その中で, ， ウサギの遺存骨および歯は地表面より $-450 \mathrm{~cm}$ 以 下の下層部から集中的に出土しており，上半部の 層位には稀であった ${ }^{31}$ 。 $\mathrm{C}^{14}$ による年代測定の結果 では，上層部の-95 127 cm で7, 920土80年 B.P. (Gak-1054), $\quad-462 \mathrm{~cm}$ で $8,590 \pm 160$ 年 B.P.

(Gak-3771)，最下層に近い $-534 \sim 535 \mathrm{~cm}$ で $8,870 \pm 220$ 年 B.P. (Gak-3773) という值が得ら れている。したがって出土ノウサギは約 8,500〜 9,000 年以前に 生存していたものとみてよいだろ う。

遺跡の位置する長野県東部地方で採集された現 生ノウサギと, 杤原遺跡出土ノウサギの遺存体に ついて，上顥第 2 切歯以外の全歯種および頭蓋骨 の 3 計測部位で大きさを比較した。その結果, 歯 においては煩歯歯冠の近遠心径・煩舌径・Rectangle が早期繩文時代産で全般的に大型であったこ

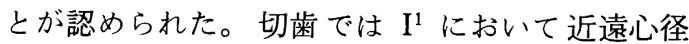
に変化がなく，煩舌径と Rectangle が大型であ り， $I_{1}$ においては近遠心径・煩舌径・ Rectangle の 3 者とも時代的な差が認められなかった。頭蓋 骨の 3 部位においては，有意な差ではないものの 平均值では早期繩文時代産で大であった。

前報6)において，著者らは早期繩文時代産ノウ サギの四肢骨が現生のものに対して 全般的に大型 であったことを報告し，その原因を当時の寒冷気 候に求めた。早期繩文時代の年平均気温は，現在 のそれより2 3 ${ }^{\circ} \mathrm{C}$ 低かったものと推定されてい
る ${ }^{13)}$ からである。本報において煩歯や頭蓋骨にお いても四肢骨と同様に大型であったことが認めら れたので， 約 $8,500 \sim 9,000$ 年前のノウサギは同一 地域の現生のものと比較して煩歯や頭蓋骨を含む 体全体が大型であったことが明らかである。

寒冷地方に住む哺乳動物の体は, 同種の温暖地 方に住むものより大型化しているのが普通であ り，この現象は「ベルグマンの法則」と呼ばれて いる。体が大型であることは体表面積を相対的に 小さくし，体表からの熱の放散を抑制する効果が ある。また，寒冷な気候の下ではノウサギの主食 になる植物体の葉や茎などの 緑色部を利用できる 期間が短く，樹皮のような粗剛な食物を利用する ことが多かったであろう。歯の大型化は，咬合面 の拡大によって咀嚼機能を高めるとともに，摩耗 に対する耐久力を増す。一般に体の大きさと歯の 大きさの間には高い正の相関が認められており ${ }^{14)}$, ノウサギの場合も歯の全般的な大型化が体の大型 化を支える基盤となっているにちがいない（宮 尾 ${ }^{15)}$ ， 参照)。歯の大きさの一次元計測值による 時代較差をみると有意差のある 部位ではその幅が 2.92 ( $\mathrm{P}^{4}$ 煩舌径) 7.17 ( $\mathrm{M}_{3}$ 近遠心径) \%であ る。前報 ${ }^{6)}$ において，四肢骨の大きさの一次元計 測值の時代較差の幅は，有意差のある部位で 2.88 （尺骨滑車切痕幅） 7.58 (肩甲頸厚) \%であっ たから，ノウサギの体の大型化は，四肢骨と歯で 平行的におこっていたと考えられる。このよう に，歯や体の 全般的な大型化が認められること は，寒冷気候に対するきわめて 重要な適応である と考えられる。

次に歯の大きさの時代較差を歯種別に検討する と, 煩歯については, 上・下顎とも, 歯列の中央 部に位置する歯で時代較差が大であり，両端に位 
置する歯ではそれが小さい。一方, 現生ノウサギ の煩歯について，その大きさの変異性を比較する と, 歯列の両端に位置する歯で変異係数が大であ り, 中央部に位置する歯でそれが小さい。すなわ ち, 歯の大きさの変異性と歯の大きさの時代較差 との間には負の相関関係が認められた。

一般に, 高い変異性を示すのは, 厳密に統合さ れていない形質，機能的に意味をもたない形質， 痕跡的な形質であるのが普通であり ${ }^{16)}$ ，ノウサギ の歯列では, 上頡第 2 切歯や上・下顎の第 3 大臼 歯がそれにあたる。このような形質は, 適応の構 成上, 重要な役割を担うことはないであろう。複 雑な機能を有し，適応のより重要な構成分子とな る形質では, 正常な機能を営むためには変異性が 抑制されなければならない。歯の大きさの変異性 は, occlusal complexityに反比例する, といわれ るのである17)。

形についても，大きさについても安定しており， 機能の上で中心的な役割を演ずる, Dahlberg ${ }^{18)}$ のいう Key teeth で，時代較差が大きいことは， この変化が適応的に重要な 意味をもっていること を示すものであるといってよい。すなわち，煩歯 列の中心部に位置する歯が大型化することによっ てその役割が強調されることになり，より強力で 効率の高い咀嚼機構が獲得されることを意味して いる。

ノウサギの場合, 㛲歯列の中央部に位置する第 1 ・第 2 大臼歯は, 両端に位置する歯より上・下 顎とも萌出が早い(19) ことも，これらの歯が機能中 心であることを意味しているだろう。

瀬戸内海屋代島産のタヌキ(Nyctereutes procyonoides) は九州本土産のそれに比し, 歯が全般 的に小型化しており, 島の生活環境に対する適応 形態とみられているが, 小型化の最も著しいのは, 変異性の最も小さい下䅡第 1 大臼歯であった ${ }^{20)}$ 。

また, ノウサギの切歯については, 時代較差の 認められたのは上㖽第 1 切歯の唇舌径のみで, そ の近遠心径ならびに下顎切歯の近遠心径および唇 舌径には時代較差が認められなかった。切歯の大

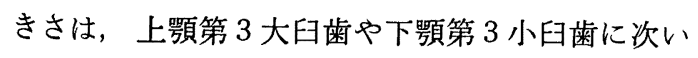
で個体変異の大きい形質であった。Gigantopithecus blacki は進化の過程で歯の大きさを増大して
いるが, それは主として postcanine teeth で生起 し, anterior teeth には変化が小さい211。また, Australopithecus の進化の過程においても同様な 現象がみられている221。そして，両者のいずれに おいても, posterior teeth row のうち, 特に中心 部の歯における大きさの増加が著しいという。こ れらの場合も, より強力で効率のよい咀嚼機構の 獲得を意味していると考えられている ${ }^{21)}$

摂食に関係した器官の形態学的特徵は, 生態学 的特性と密接に結びついているのが一般であるか ら，早期繩文時代のノウサギは， 臼磨運動により 大きな力を要求される 食物環境にあったことが示 唆されるのである。当時の寒冷気候とそれに伴な う植生の状態などが，食物環境の重要な因子とな っていたのではなかろらか。現生ノウサギの小型 化は, 島嶼型への变化や, 人為的な植生の改変な どもその原因の一部になっているかもしれない。

中米のPeromyscus maniculatus は, 森林環境 (woodland) と開けた植生環境 (open habitat)に 生息するものとの間で, 下顎骨や歯の特徴に若干 の差異が認められ, 前者でオトガイ孔一切歯間距 離, 下顎枝の高さ, 下頡第 1 大臼歯などが大であ るという。そして, 先史時代遺跡 (A.D. 1,200 1,400 年）から出土寸る下䪽骨についてみると, 比較的新しい遺跡のものほど open habitat タイプ が増加する現象が報告されている ${ }^{23)}$ 。この原因と しては, 気候変化に伴なう森林の縮小に加えて, ヒトによる森林破壊が考えられるという ${ }^{23 !} 。$

先に報告した早期繩文時代産と現生のアカネズ ミ(Apodemus speciosus) の下䫟歯の比較 ${ }^{4)}$ では, 前者で歯が大型であった点は本報のノウサギの場 合に一致する。しかし, アカネズミの場合, 時代 較差が最も大きかったのは第 3 大臼歯で, 萌出が 早く，機能中心である第 1 大臼歯で差が小さかっ た。ノウサギとアカネズミの間にみられるこの矛 盾が何を意味しているのか, 今は明らかでない。

第四紀における日本産哺乳動物の 形態学的変化 に関する研究は近年始まったばかりであり（河 村 ${ }^{24)}$, 参照), 哺乳類の歯の変異性についても時 代的変異と地理的変異 - 個体変異を関連させた研 究はほとんどない。したがって，これらの変異が 歯種ごとにどのような様相を示しているのかにつ 
いては全く知られていないといってよい。いずれ にせよ, 本報では年平均気温で $2 \sim 3^{\circ} \mathrm{C}$ 低かった 早期繩文時代の歯の全般的な大型化が ノウサギに おいても確認されたことが重要であり，歯種ごと の変異性の解析は今後の課題としたい。

西中川ほか ${ }^{25)}$ は鹿児島県の繩文後・晚期の哺乳 動物骨を調查し, 当時のノウサギ・シカ・イノシ シが現生のものより幾分大きかったことを 報告し ている。晚期繩文時代の年平均気温は，現在より
約 $1{ }^{\circ} \mathrm{C}$ 低かったと考えられている ${ }^{13)}$ ので，ノウ サギの大型化は繩文後・晚期にも起こっていたの かもしれない。年平均気温が現在より $2^{\circ} \mathrm{C}$ ほど 高かったとされる前期繩文時代の資料との比較に 興味がもたれる。ただし，日本産ノウサギの体の 大きさの地理的変異の全貌が 把握されておらず, 系統論も 確立されていない現時点では（宮尾ほ $か^{6)}$, 参照), その時代的変異についての論議はな かなかむずかしい。

抄録 : 早期繩文時代長野県枋原岩蕯遺跡下層部（約 8,500 9, 000 年前）より出土したノウサギの歯および 頭蓋骨の大きさを長野県東部地方産ノウサギのそれと比較検討した。

歯に扔いては煩歯の全般的な大型化が早期繩文時代産で認められたが，切歯では時代的変化の認められな い部位が多かった。時代較差の大きかった煩歯列中央の歯は, 現生個体で変異性の低い歯であった。頭蓋骨 に㧧いては，有意な差ではないものの平均值では早期繩文時代産で大であった。

早期繩文時代の年平均気温は現在より $2 \sim 3{ }^{\circ} \mathrm{C}$ 低かったとされており, ノウサギの煩歯や頭蓋骨の大型化 はこうした気候条件の差異と関係があるものと考えられた。

\section{文献}

1）鈴木 誠：長野県北相木村杤原岩䔖遺跡之人 骨. 人類誌 $76: 52-54,1968$.

2）西沢寿晃，杤原岩陰遺趾. 長野県史，考古資料 編 全 1 巻 (2) pp. 559-584, 長野県, 長 野, 1982.

3）宮尾灣雄, 西沢寿晃, 鈴木茂忠 : 早期繩文時代 長野県杤原岩蕯遺跡出土の哺乳動物. 第 1 報. 出土哺乳動物相. 哺乳動物学雑誌 8:181-188, 1980.

4）宮尾暾雄, 酒井英一, 西沢寿晃: 同上. 第 2 報. アカネズミ下頡大臼歯の大きさ，歯基礎誌 23 : 141-146, 1981.

5）西沢寿晃, 宮尾獤雄 : 同上. 第 3 報. ニホンザ ルの遺存骨. 長野県考古学会誌 41:1-10, 1981.

6) 宮尾徽雄, 西沢寿晃, 子安和弘: 同上. 第 4 報. ノウサギ四肢骨の大きさ。成長 $21: 20-27,1982$.

7）宮尾猄雄, 子安和弘, 西沢寿晃 : 早期繩文時代 出土イノシシの煩歯の大きさ. 成長 $20: 234-$ 235, 1981

8）河村善也：帝勫観音洞窟遺跡土器伴出層準出土 の小型哺乳動物遺体. 第 1 報. 広島大学文学部 帝釈陕遗跡群発掘調査室年報 1:55-67, 1978 .

9）大塚潤一, 豊満義邦, 西中川駿 : キュウシュウ ノウサギ, アマミノクロウサギおよび家鬼 J W-NIBS の骨の計測值について。 I . 頭蓋㧍 よび胴骨. 実呀動物 29:441-455, 1980.

10）今泉吉典：原色日本哺乳類図鑑，pp. 110-113, 保育社, 大阪, 1960 .

11）山田文雄, 白石 哲: 産地の異なるノウサギ個 体群における外部形質および頭骨の大きさの比 校. 動物学雑誌 $87: 546,1978$.

12）宮尾獤雄, 水野武雄 : 長野県産ノウサギの地方 変異, 日本哺乳類䧴記, 第 2 集, pp. 16-22. 信州哺乳類研究会, 松本, 1973.
13）安田喜憲：環境考古学事始, 日本放送出版協会, 東京, 1980 .

14) Gould, S. J.: On the scaling of tooth size in mammals. Amer. Zool. $15: 351-362,1975$.

15）宮尾㺟雄 : 哺乳類に おける歯の大きさの変異 (I). 成長 $20: 60-74,1981$.

16) Simpson, G. G.: The Major Features of Evolution, Columbia Univ. Press New York, 1953.

17) Gingerich, P. D. and Shoninger, M. J. : Patterns of tooth size variability in the dentition of Primates. Am. J. Phys. Anthrop. 51 : 457-466, 1979.

18) Dahlberg, A. A.: The changing dentition of man. J. Amer. Dent. Ass. 32:676-690, 1945.

19）宮尾獤雄, 西沢寿晃 : 長野県産ノウサギにおけ る歯数異常と煩歯の萌出順序. 成長 $10: 69-74$, 1971.

20）宮尾彎雄, 小池義国 : 山口県屋代島産タヌキの 頭骨および歯の大きさ.成長 $21: 69-79,1982$.

21) Yinyun, Z.: Variability and evolutionary trends in tooth size of Gigantopithecus blacki. Am. J. Phys. Anthrop. 59 : 21-32, 1982.

22) Wolpoff, M. H. : Paleoanthropology. Alfred A. Knopf, New York, 1980.

23) Holbrook, S. J. : Ecological inferences from mandibular morphology of Peromyscus maniculatus. J. Mamm. 63 : 399-408, 1982.

24）河村善也：第四紀における哺乳動物の大きさの 変化. 成長 $20: 191-194,1981$.

25）西中川駿, 松元光春, 大塚潤一, 河口貞徳 : 鹿 児島の繩文, 弥生遺跡出土の哺乳動物. 1. 中 岳, 片野および黒川洞穴の出土骨について, 昭 和58年度日本哺乳動物学会大会講演要旨. p. $13,1983$. 